\title{
Sistem Informasi Perbaikan Komputer Di Aditama Computer Boyolali Berbasis Android
}

\author{
Ahmad Jamaludin a,1,*, Donna Setiawati a,2, Fariyono, ${ }^{\mathrm{a}, 3}$ \\ ${ }^{a}$ Fakultas Ilmu Komputer, Universitas Boyolali, Jalan Pandanaran no. 405, Boyolali 57314, Indonesia \\ ${ }^{1}$ ahmadad3742@gmail.com *; ${ }^{2}$ donna.setiawati@gmail.com; ${ }^{3}$ ayah.fari@yahoo.com \\ * Koresponsendi penulis
}

ARTICLE INFO

Article history

Menerima 2 Mei 2020

Revisi 2 Juni 2020

Diterima 3 Juni 2020

Kata Kunci

Sistem

Android

Service

Informasi

\section{ABSTRACT}

Service acceptance system or repairs carried out by this company is still simple, namely by way of manual bookkeeping done by the service admin. The obstacle currently faced by implementing the system is that the admin feels overwhelmed in serving. This is due to an increase in the number of customers and Admin often get questions from customers about the repair history of their computer devices whether they have been repaired or not. This results in reduced levels of customer satisfaction due to slow service. The services provided are less than optimal because on the other hand the service admin duties within the company do not only serve incoming computer devices. This service information system was built using the waterfall method. The results of this study are that this Android-based system can replace the old administration system so as to ease the burden of service admin in serving customers and improving service quality

This is an open access article under the CC-BY-SA 4.0 license.

\section{Pendahuluan}

Aditama Computer merupakan salah satu perusahaan yang bergerak dibidang penjualan dan servis Komputer seperti penjualan PC, Laptop, Printer, dan aksesoris komputer serta melayani servis. Selain melayani servis komputer juga melayani instalasi proyektor, CCTV, dan LAN. Usaha ini berdiri sejak tahun 2001 dan beralamat di Jalan Kenanga No. 14 Kota Boyolali Provinsi Jawa Tengah.

Sistem penerimaan servis atau perbaikan yang dilakukan oleh perusahaan ini masih sederhana, yaitu dengan cara pembukuan manual yang dilakukan oleh admin servis. Kendala yang dihadapi saat ini dengan menerapkan sistem tersebut adalah admin merasa kewalahan dalam melayani. Hal ini dikarenakan adanya kenaikan jumlah pelanggan dan Admin sering mendapat pertanyaan dari pelanggan tentang riwayat perbaikan perangkat komputernya apakah sudah selesai diperbaiki atau belum. Hal ini berakibat pada tingkat kepuasan pelanggan berkurang karena pelayanan yang lambat. Pelayanan yang diberikan kurang maksimal karena di sisi lain tugas admin servis dalam perusahaan tersebut tidak hanya melayani perangkat komputer yang masuk.

Dalam rangka meningkatkan pelayanan sehingga pelanggan puas maka berdasarkan permasalahan yang telah dijelaskan sebelumnya maka perlu adanya sistem yang dapat memberikan informasi mengenai perkembangan perangkat komputer yang sedang diperbaiki. Informasi yang dibutuhkan oleh pelanggan tersebut dapat langsung diakses melalui smartphone. Sistem informasi 
adalah cara-cara yang diorganisasi untuk mengumpulkan, memasukkan, dan mengolah serta menyimpan data, dan cara-cara yang diorganisasi untuk menyimpan, mengelola, mengendalikan, dan melaporkan informasi sedemikian rupa sehingga sebuah organisasi dapat mencapai tujuan yang telah ditetapkan [1]. Penerapan teknologi informasi dalam bidang bisnis merupakan salah satu contoh untuk memenuhi akan kebutuhan informasi yang demikian besar terlebih lagi teknologi ini juga mempunyai nilai akurasi data yang tinggi dalam menunjang keputusan bisnis sehingga pekerjaan akan jauh lebih efektif dan efisien. Teknologi informasi tidak hanya terbatas pada teknologi komputer (perangkat keras dan perangkat lunak) yang akan digunakan untuk memproses dan menyimpan informasi, melainkan juga mencakup teknologi komunikasi untuk mengirim atau menyebarkan informasi pendukung keputusan dan sistem informasi [2].

Pada masa sekarang proses pencatatan dengan menggunakan media digital lebih efektif dan efisien. Penelitian tentang sistem informasi servis ini telah dilakukan oleh beberapa peneliti. Penelitian yang dilakukan oleh [3] yaitu membuat sistem informasi pencatatan servis mobil di PT. Armada International Motor Magelang Berbasis Android. Hasil penelitiannya adalah dengan adanya aplikasi ini dalam proses bisnis sebelumnya membutuhkan 13 kali tahapan, sedangkan dalam proses bisnis yang baru hanya membutuhkan 7 kali tahapan. Hal inilah yang akan dilakukan pada sistem baru pada Aditama Computer yaitu mempersingkat tahapan proses bisnisnya. Pelanggan tidak harus menelepon untuk mengetahui status barangnya yang sedang diperbaiki. Namun informasi tersebut dapat dilihat melalui smartphonenya.

Dengan dibangunnnya sistem informasi servis atau perbaikan komputer berbasis android diharapkan dapat memaksimalkan pelayanan terhadap pelanggan Aditama Computer. Hal ini karena pelanggan dengan realtime dapat memantau pengerjaan perbaikan perangkatnya.

\section{Metode Penelitian}

Sistem informasi servis ini dibangun menggunakan metode waterfall. Metode air terjun atau yang sering disebut metode waterfall sering dinamakan siklus hidup klasik (classic life cycle). Siklus ini menggambarkan pendekatan yang sistematis dan juga berurutan pada pengembangan perangkat lunak, dimulai dengan analisis kebutuhan perangkat lunak (Requirement), desain (Design) perangkat lunak, pembuatan kode program (Implementation), pengujian (Verification) dan pemeliharaan (maintenance). Dalam pembuatan sistem tidak menutup kemungkinan sebuah perangkat lunak mengalami perubahan ketika sudah dikirimkan ke user. Perubahan bisa terjadi karena adanya kesalahan yang muncul dan tidak terdeteksi saat pengujian atau perangkat lunak [4].

Pada tahap analisis kebutuhan perangkat lunak, untuk mendapatkan informasi tentang kebutuhan user maka dilakukan pengumpulan bahan dengan berbagai cara yaitu 1) Wawancara, untuk mengetahui masalah yang berhubungan dengan sistem penerimaan servis di Aditama Computer. Wawancara dengan admin servis perusahaan tersebut, dengan tujuan mendapatkan informasi proses penerimaan perbaikan masuk dari pelanggan, form input perbaikan masuk, dan data arsip perbaikan. 2) Observasi, kegiatan pengumpulan data dilakukan dengan langsung melihat kegiatan yang dilakukan. Serta pengamatan langsung ke objek penelitian untuk memperoleh data serta keterangan terhadap sistem yang sedang berjalan. Tempat yang menjadi objek penelitian adalah Aditama Computer Boyolali yang beralamat di Jalan Kenanga No. 14 Boyolali. Waktu observasi pada hari jam kerja yaitu dari Senin sampai dengan Sabtu pukul 08.00 sampai pukul 16.30 WIB. 3) Studi Kepustakaan dengan membaca dan mempelajari bahan-bahan yang berasal dari buku-buku, jurnal atau artikel.

Pada tahap perancangan sistem digunakan UML (Unified Modeling Language) yang berfungsi untuk menggambarkan prosedur dan proses kerja aplikasi. Dalam konteks UML, tahap konseptualisasi dilakukan dengan pembuatan Use case diagram yang sesungguhnya merupakan deskripsi peringkat tinggi bagaimana perangkat lunak akan digunakan oleh penggunanya. Selanjutnya use case diagram tidak hanya sangat penting pada tahap analisis, tetapi juga sangat penting untuk perancangan, untuk mencari kelas-kelas yang terlibat dalam aplikasi, dan untuk melakukan pengujian [5].

Membuat use case diagram yang komprehensif merupakan hal yang sangat penting dilakukan pada tahap analisis. Setiap objek yang berinterkasi dengan sistem atau perangkat lunak merupakan actor untuk sistem tersebut. Sementara use case merupakan deskripsi lengkap tentang bagaimana sistem atau perangkat lunak berperilaku untuk para actor-nya. Dengan demikian, use case diagram 
merupakan deskripsi lengkap tentang interaksi yang terjadi antara para actor dengan sistem atau perangkat lunak yang sedang dikembangkan. Pada Gambar 1 dijelaskan bahwa actor yang berinteraksi dengan sistem adalah Admin. Admin sebagai actor berinteraksi dengan sistem servis atau perbaikan ini dengan melakukan perilaku-perilaku antara lain melakukan login, menginputkan data barang yang akan diperbaiki atau servis, edit data, view data, update data dan logout.

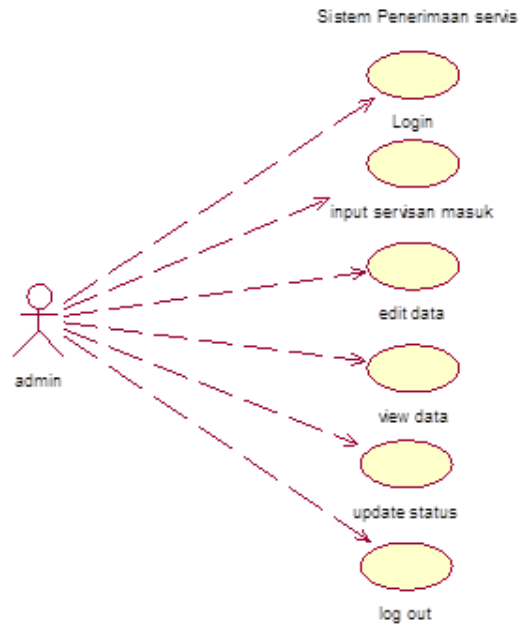

Gambar 1. Use case diagram admin

Langkah selanjutnya setelah membuat use case diagram adalah membuat activity diagram agar bisa mendapatkan gambaran secara menyeluruh atau terinci dari perilaku sistem untuk masing-masing use case yang ada.

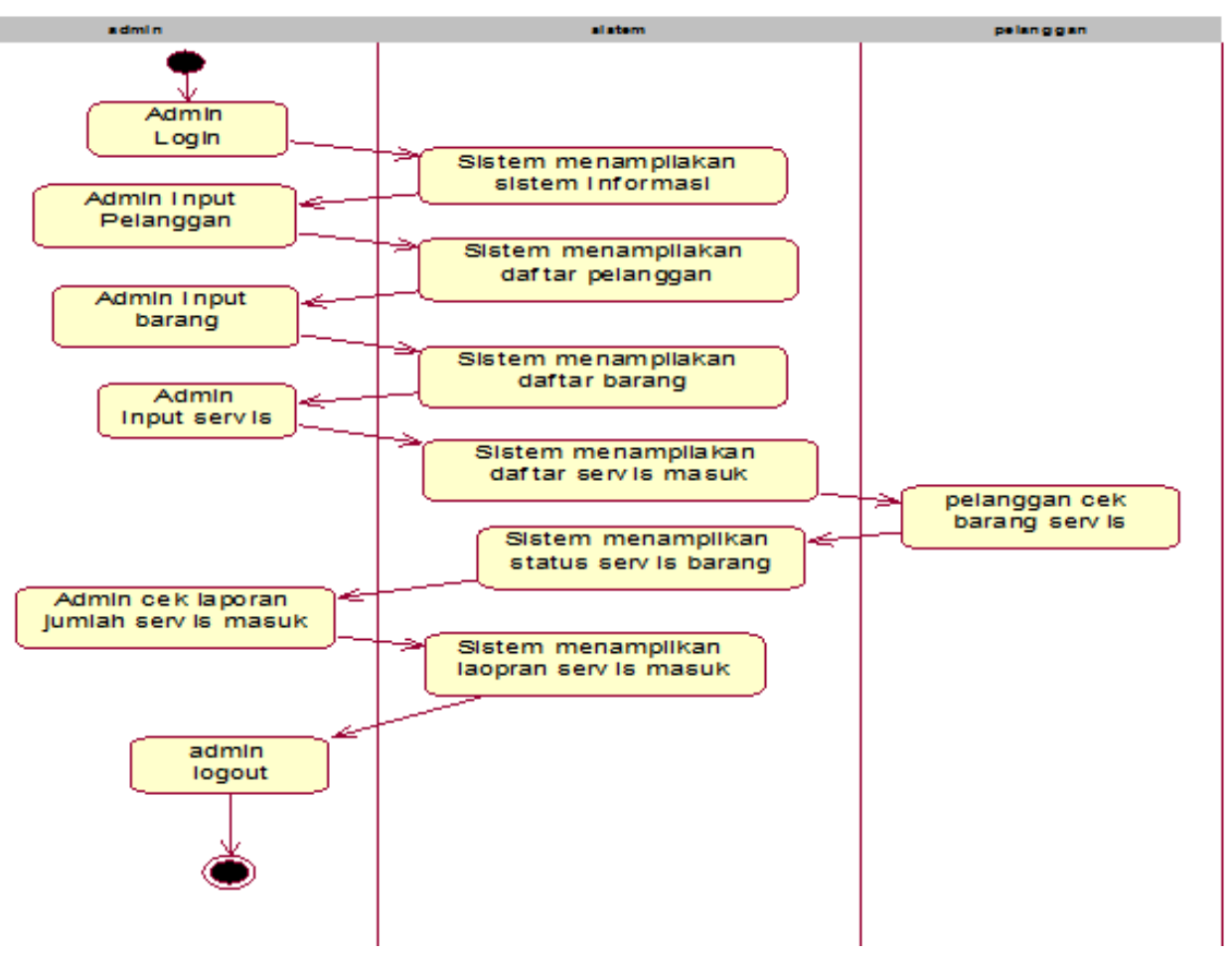

Gambar 2. Activity Diagram 
Pada Gambar 2 dapat dijelaskan bahwa use case penerimaan barang yang akan diperbaiki atau servis, activity diagram-nya adalah sebagai berikut:

a. Admin login ke sistem

b. Sistem akan menampilkan sistem informasi

c. Admin memasukkan data pelanggan

d. Sistem akan menampilkan data pelanggan

e. Admin memasukkan data barang

f. Sistem akan menampilkan data barang

g. Admin memasukkan data servis

h. Sistem akan menampilkan data servis

i. Pelanggan cek status barang yang diservis

j. Sistem menampilkan status barang yang diservis

k. Admin mengecek laporan barang masuk

1. Sistem akan menampilkan laporan barang masuk

m. Admin logout

\section{Hasil dan Pembahasan}

Pada tahap implementasi ini merupakan penerapan yang diperoleh dari analisa kebutuhan sampai dengan konstruksi untuk mewujudkan sistem informasi yang diusulkan. Pengembangan sistem dilakukan dengan software android studio, visual studio, code bahasa pemrograman HTML, PHP serta dengan framework code igniter. Sistem informasi ini dirancang sebagai media administrasi penerimaan servis secara online bagi Aditama Computer yang selama ini hanya melakukan administrasi secara tradisional dengan menggunakan rekap data pelanggan secara manual. Tampilan halaman utama seperti pada Gambar 3. Pada halaman utama terdapat 3 (tiga) menu yaitu menu master, menu pelayanan dan menu laporan.

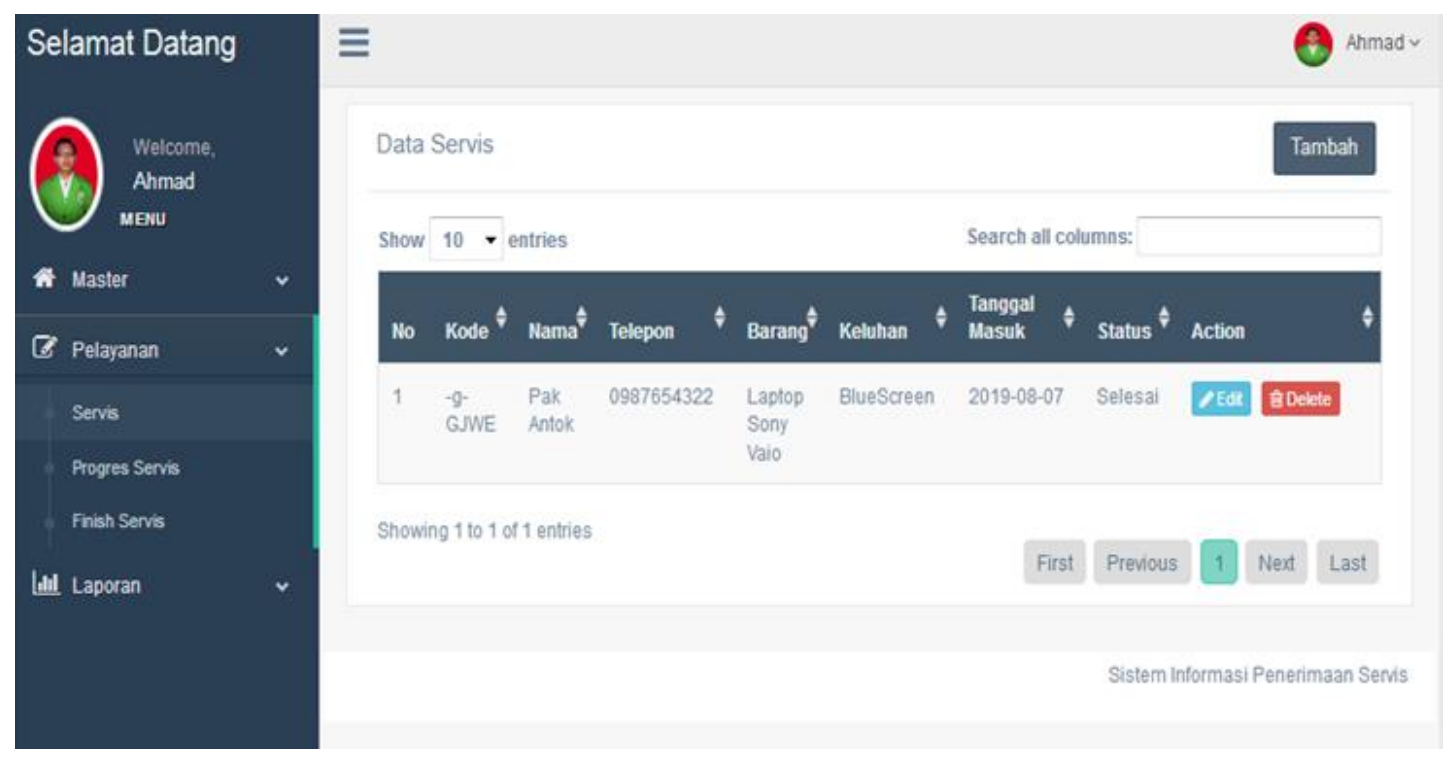

Gambar 3. Implementasi Halaman Utama Sistem

Pada menu master berisi menu pelanggan dan menu barang. Admin memasukkan data pelanggan yang datang untuk servis. Admin akan melakukan pencatatan nama pelanggan, alamat rumah, alamat kantor (jika ada), dan nomer telepon. Data pelanggan ini akan disimpan dalam database sehingga apabila diperlukan kembali akan mudah ditemukan. Menu tampilan data pelanggan dapat dilihat seperti pada Gambar 4. Selain data pelanggan, Admin juga memasukkan data barang yang berisi data perangkat komputer dan perangkat elektronik lainnya yang bisa diperbaiki di Aditama Computer. Menu tampilan data barang dapat dilihat seperti pada Gambar 5. 


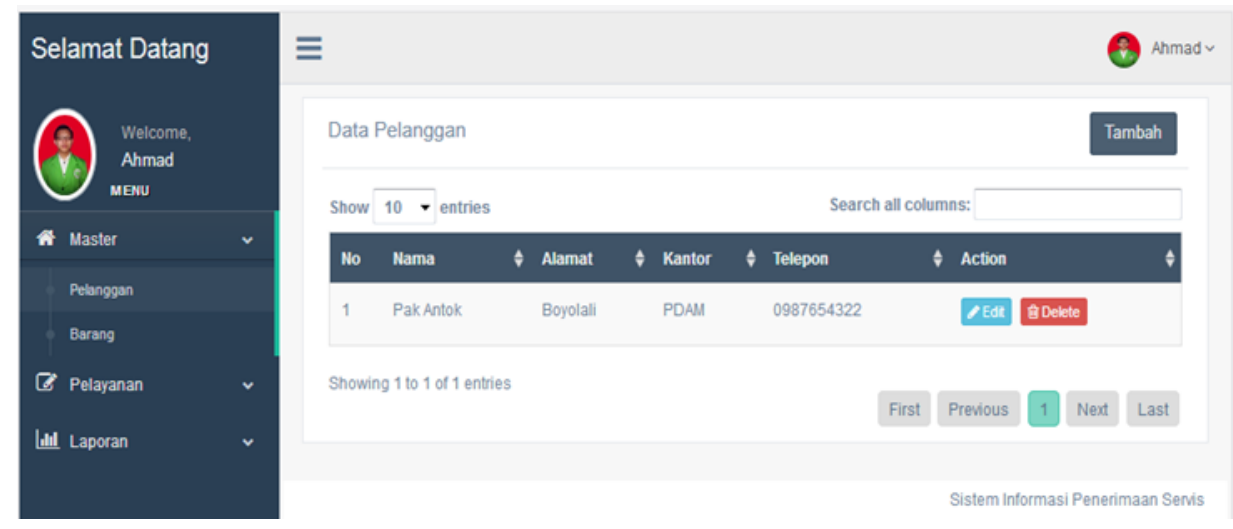

Gambar 4. Implementasi Data Pelanggan

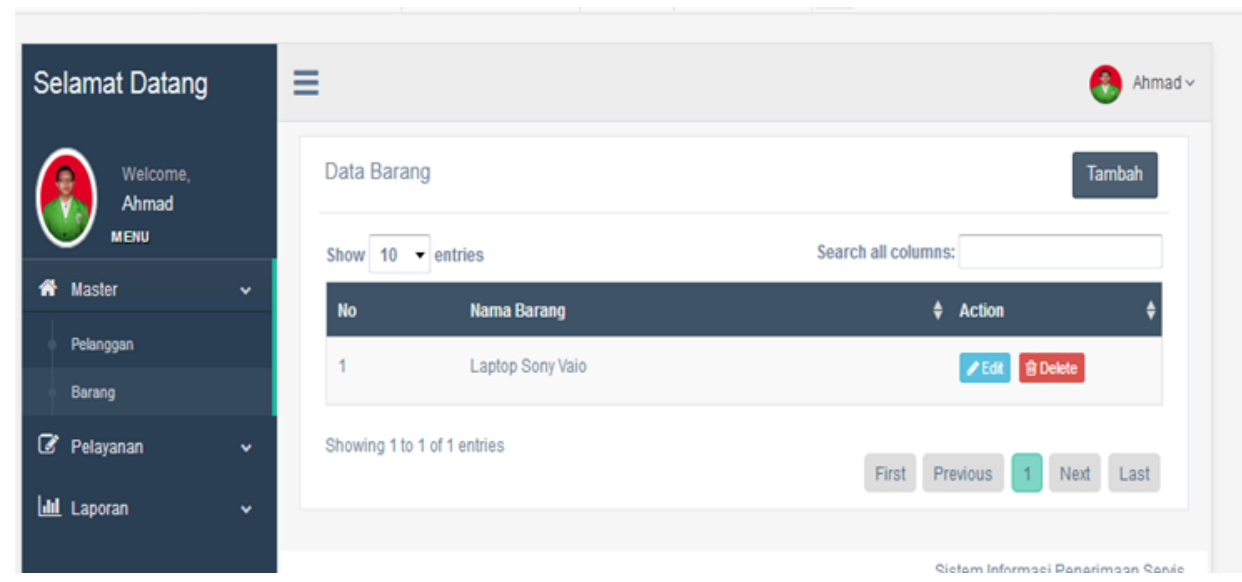

Gambar 5. Implementasi Data Barang

Pada menu pelayanan terdapat 3 (tiga) menu yaitu servis, progress servis dan finish servis. Barang yang masuk oleh admin akan dimasukkan kedalam menu servis untuk dicatat sebagai barang yang masuk daftar antrian perbaikan barang. Setelah itu jika barang tersebut sudah dalam proses perbaikan oleh teknisi maka data barang tersebut masuk pada menu progress servis. Selanjutnya tahap terakhir jika barang telah selesai diperbaiki oleh teknisi maka status barang tersebut masuk pada menu finish servis.

Pada form data perbaikan masuk yang akan dicatat adalah nama pelanggan, telepon, barang, keluhan, tanggal masuk, status dan kode. Pada transaksi ini akan didapatkan kode unik. Kode unik tersebut yang nantinya bisa diakses pelanggan untuk mengecek sampai mana proses pengerjaan perangkat yang sedang diperbaiki, tampilan form data perbaikan masuk seperti pada Gambar 6 . Aplikasi ini juga dilengkapi dengan menu Laporan. Pada menu laporan ini admin dapat mengontrol jumlah perangkat komputer yang masuk, yang masih antria untuk dikerjakan, yang sedang dikerjakan dan yang telah selesai diperbaiki. Tampilan menu laporan seperti pada Gambar 7.

Pelanggan dapat melakukan tracking atau penelusuran perangkatnya melalui aplikasi yang sudah terinstal di smartphone nya. Pelanggan memasukkan kode unik yang telah diberikan sebelumnya oleh Admin saat pelanggan mendaftarkan barangnya masuk untuk diperbaiki. Tampilan form tracking seperti pada Gambar 8.

Pengujian sistem dilakukan untuk memastikan bahwa aplikasi yang dibangun telah sesuai dengan harapan dan telah memenuhi kebutuhan user. Pengujian aplikasi ini menggunakan pendekatan black-box testing. Pengujian black box adalah pengujian aspek fundamental sistem tanpa memperhatikan struktur logika internal perangkat lunak. Metode ini digunakan untuk mengetahui apakah perangkat lunak berfungsi dengan benar [6]. Uji coba pada sistem ini menunjukkan hasil 
sesuai dengan yang diharapkan. Login admin hasil akurat, input data pelanggan dan barang sesuai harapan, yaitu dapat untuk menginputkan data baru. Input data servis dan input kode unik juga sudah sesuai harapan.

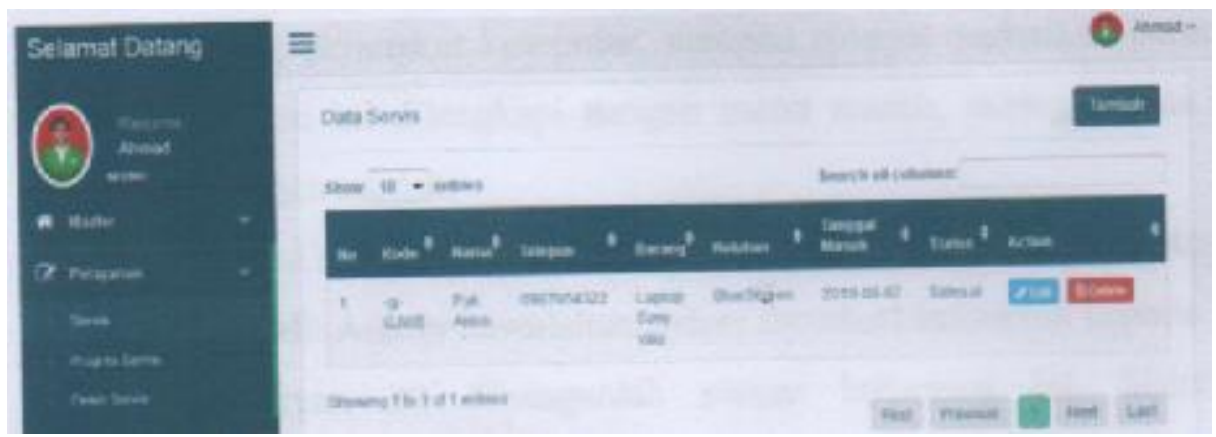

Gambar 6. Form data perbaikan masuk

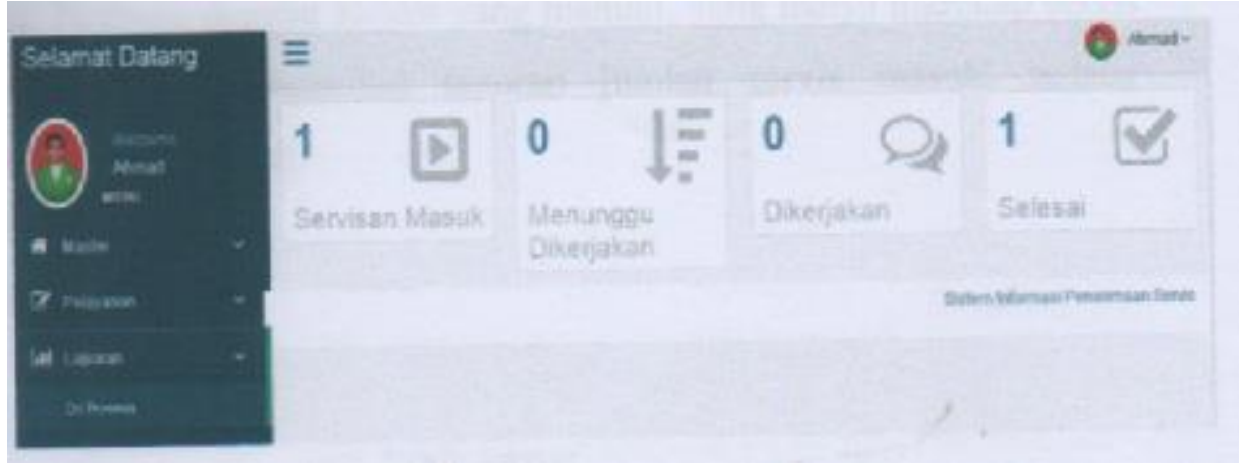

Gambar 7. Menu laporan

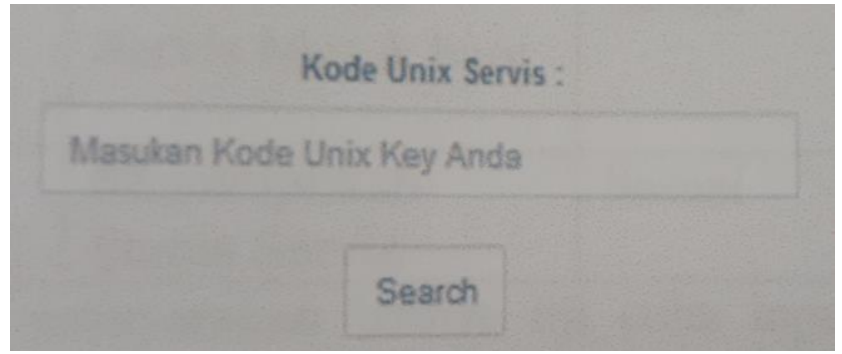

Gambar 8. Form Tracking

Pada sistem yang lama untuk dapat mengetahui perkembangan proses perbaikan, pelanggan harus melakukan telepon dan admin tidak dapat langsung bisa menjawab. Hal ini admin harus menanyakan terlebih dahulu ke bagian teknisi dan membuka catatan. Jika pada kesempatan yang sama bagian teknisi tidak ditempat maka dapat dipastikan admin tidakdapat memberikan jawaban yang pasti kepada pelanggan kapan barangnya selesai. Hal ini akan membuat pelanggan kecewa. Tahapan proses bisnis pada sistem yang baru ini lebih ringkas, karena pelanggan langsung bisa mendapatkan informasi terkait perkembangan barang yang sedang diperbaiki dengan hanya memasukkan kode unik dalam smarphonenya.

Hasil penelitian ini sejalan dengan penelitian yang dilakukan oleh [7] yaitu sistem yang diusulkan untuk pelayanan jasa perbaikan dan perawatan elektronik pada CV. Sumber Teknik Cool, dapat lebih memberikan kemudahan dan sistem lebih terkomputerisasi dengan baik dari sistem sebelumnya yang masih menggunakan aplikasi untuk umum (microsoft excel). Selain itu sistem juga dapat meningkatkan kinerja Customer Service terutama dalam pengelolaan data pelanggan dan data Service perbaikan dan perawatan elektronik serta data-data dapat terorganisir lebih baik dan menghasilkan laporan yang akurat. 


\section{Penutup}

Dari pembahasan yang telah diuraikan maka dapat disimpulkan hasil penelitian ini adalah sistem telah berhasil dirancang, diimplementasikan, dan diuji. Sistem berbasis android ini dapat menggantikan sistem administrasi yang lama sehingga meringankan beban admin servis dalam melayani pelanggan dan meningkatkan kualitas pelayanan.

Saran yang dapat diberikan adalah sistem dapat dikembangkan lagi sesuai kebutuhan, tergantung kendala-kendala yang nantinya akan ditemukan. Sebagai contoh sistem bisa berintegrasi dengan sistem informasi penjualan. Sistem akan lebih optimal apabila konfirmasi tentang setiap status perbaikan langsung terintegrasi dengan pesan singkat.

\section{Daftar Pustaka}

[1] Krismiaji, 2015, Sistem Informasi Akuntansi, Unit Penerbit, Yogyakarta.

[2] Ariston, 2017, Rancang Bangun Sistem Informasi Servis Motor Pada Bengkel Pandan Sari Motor Trenggalek, Skripsi, Program Studi Sistem Informasi Fakultas Teknik Universitas Nusantara PGRI Kediri, http://simki.unpkediri.ac.id/mahasiswa /file_artikel/2017/12.1.03.03.0186.pdf (Diakses Tanggal 2019).

[3] Christine Dewi, Kumala Nindya Pramono, Pembuatan Aplikasi Pencatatan Servis Mobil di PT. Armada International Motor Berbasis Android, JNTETI, Vol. 4, No. 4, November 2015, Departemen Teknik Elektro dan Teknologi Informasi, Fakultas Teknik Universitas Gadjah Mada, Yogyakarta.

[4] R.S.Pressman, 2012, Rekayasa Perangkat Lunak Buku Satu: Pendekatan Praktisi (Edisi 7), Penerbit Andi, Yogyakarta.

[5] Nugroho Adi, 2009, Rekayasa Perangkat Lunak Menggunakan UML dan JAVA, Penerbit ANDI, Yogyakarta.

[6] William, Laurie. 2006, Testing Overview and Black Box testing technique, 35-59

[7] Prastomo Andi, 2015, Sistem Informasi Pelayanan Jasa Perbaikan Peralatan Elektronik CV SUMBER TEKNIK COOL. Jurnal Faktor Exacta, Universitas Indraprasta PGRI Jakarta, https://journal.lppmunindra.ac.id/index.php/Faktor_Exacta/article/view/286/272 (diakses Tanggal 1 Agustus 2019) 